\title{
Assessing Input Enhancement as Positive Factor and Its Impact on L2 Vocabulary Learning
}

\author{
Seyyed Fariborz Pishdadi Motlagh (Corresponding author) \\ Department of Foreign Languages and Literature, University of Tabriz, Tabriz, Iran \\ E-mail: Fpishdadi@yahoo.com \\ Mahdiyeh Seyed Beheshti Nasab \\ Tabriz University of Medical Sciences, Tabriz, Iran \\ E-mail: bns.violet@gmail.com
}

Doi:10.7575/aiac.alls.v.6n.1p.227

URL: http://dx.doi.org/10.7575/aiac.alls.v.6n.1p.227
Received: $18 / 10 / 2014$

Accepted: 03/01/2015

\begin{abstract}
Input enhancement's role to promote learners' awareness in L2 contexts has caused a tremendous amount of research. Conspicuously, by regarding all aspects of input enhancement, the study aimed to find out how differently many kinds of input enhancement factors such as bolding, underlining, and capitalizing impact on L2 learners' vocabulary acquiring. Furthermore, the study was conducted through a quasi-experimental design with a proficiency test to find how homogeneous the groups are. Four classes were selected as the experimental groups $(\mathrm{n}=80)$, and each class was conducted by one of the input enhancement main categories compared with the control group. Subjects attended in eight sessions to make them familiar with advantages of input enhancement in relation to vocabulary learning. Each group received different strategies but control group received no treatment and then, the researcher taught and employed those inputs in texts along with target words. Learners' progress was measured during the eight sessions of employing those inputs in responding to vocabulary questions. One-Sample Kolmogorov-Smirnov Test, One-way ANOVAs series along with LSD and post hoc comparisons showed that three inputs were effective in responding to target vocabulary words and they compared and contrasted with control group but the bolding group did better than the other groups. Finally, bolding target words were more effective in fostering L2 learners' vocabulary knowledge learning. These outcomes propose that using input enhancement to answer target words are the most useful factors, especially bolding as a significant input in this study outperformed the other ones in developing learners' awareness to answer vocabulary tests. It can also be concluded that capitalizing is the least effective input compared to underlining and bolding in terms of their efficacy.
\end{abstract}

Keywords: Focus on form and Implicit Fonf, Input enhancement as focus on form, Vocabulary

\section{Introduction}

Conspicuously, L2 acquisition is evidenced as an enhancing attention in the opinions that draws subjects ideas to the formal specialties of (L2) input and emphasis that it is advantageous, and in some cases vital for optimal L2 development (Schmit, 1993). Furthermore, focus on Form is deeply related to a special kind of form focused instruction, i.e., the handling of linguistic form in the context. On the other hand, learners are capable to receive linguistic forms with no instructional mediation; so typically do not reach to top levels of linguistic competence from whole meaning-centered instruction. According to Doughty and Williams (1998), focus-on-form clarifications range narrowly and implicitly as taken from Long (1991) to an extended, and more vivid view as declared by Dekeyser (1998). One of the tacit methods of FonF instruction is input enhancement. Sharwood Smith (1991), aimed at growing the learners' attention outset by making the input prominent through utilizing varied aspects of it.

Accordingly, employing input takes the form of visual/textual input enhancement, in which the target forms become visually obvious. The belief about input enhancement is that, by making formal aspects of input more remarkable learners and they will be more likely to notice targeted forms, which eventuate in more intakes, the subset of the input data that becomes present for further language processing. Sharwood Smith (1991) asserts that the most apparent way to try to impact intuitive processing beneficially is by making related target forms in the input striking. Besides, He discussed that making the input salient (input enhancement) has a significantly positive effect on the rate and accuracy of L2 acquisition. As Schmitt (2008) considered, learning vocabulary is a basic part of overcoming a second language (Schmitt, 2008) and it has been one of the challenging topics in second language acquisition (SLA).

Apparently, there is a unity among vocabulary experts that lexical knowledge is the heart of language learning (Coady, 1997; Coady \& Huckin, 1997). Since vocabulary is considered as the heart of language learning, researchers are trying to make more effective methods of teaching L2 vocabulary to second language (L2) teachers and educators. Additionally, learners would like to know the ways to learn second language target vocabulary in a fast and easy way. But previous researches on implicit focus on form (FonF) have clarified that target forms are not always noticed by 
learners, proposing that externally-created salience (by the teacher) does not essentially guarantee learners' internally generated salience (Sharwood Smith, 1991, 1993). One effort to find ways of promoting both types of salience, an input enhancement research was directed in order to examine if, and how, externally-created salience may ideally converge with learners' internally generated salience. The results revealed that increasing the perceptual salience of target forms does not automatically results to learners' noticing of the forms.

\subsection{Research Question and Hypothesis}

Research Question:

Do bolding, capitalizing, underlining target words are effectual in learning L2 vocabulary?

Null hypothesis:

Bolding, capitalizing, underlining target words do not have any significant effects on L2 vocabulary learning.

Directional Hypothesis:

Bolding, capitalizing, underlining target words do have significant effects on L2 vocabulary learning.

\section{Review of the Related Literature}

\subsection{Focus on FonF}

Obviously, Long and Robinson (1998) find that FonF refers to how focal intentional resources are distributed. So, in his seminal article Long (1998) drew an important distinction between focus on form and focus on forms. Focus on forms goes back to the traditional ways of teaching linguistic elements such as structures, notions and lexical items where language is treated initially as an object to be practiced. This varies from focus on form in which the main focus is on meaning. Long strongly believes that FonF overtly draws students' attention to linguistic elements as they arise suddenly in lessons whose focus is on meaning or communication. Finally, he recognizes that vital characteristics inherent in FonF: "(1) much more attention to form occurs in lessons where the primary focus is on meaning or communication, and (2) attention to form arises in response to a communicative need". Currently, the term focus on form has been focused to fit more practical needs, also in the revised version of FonF, three defining characteristics are declared: (1) the need for learner involvement with meaning before dealing with the rules; (2) the significance of analyzing learners' linguistic needs to clarify the form that require treatment; and (3) the way treatment is done should be unassertive, that is to say, rules shouldn't be taught to seem like an absolute distinct constituent (Doughty \& Williams, 1998). While (1) and (3) are in line with Long's original definition, (2) is not, for it advocates a planned or proactive approach rather than an incidental attention to form (Elis, 2001).

Focus on forms lends itself to support the idea of teaching the formal properties of language. By teaching the formal aspects of language in isolation, this can be achieved (Sheen, 2002). Second language is broken down into its components such as words, grammar rules, phonemes and functions in focus on forms. The major drawback to focus on forms could be that it fails to develop communication-related abilities in SL learners. In other words it does not drive learners towards achieving real-world and authentic means outside classroom settings (Poole, 2005). The focus is solely on linguistic components and forms in isolation and no attention is paid to development of fluency in focus on forms (Seedhouse, 1997).With the advent of communicative language teaching, the attitude towards learning a foreign language experienced dramatic changes and provided us with a new insight into learning languages. Therefore the need to learn the formal properties of the target language was considered useless. The advocates of this theory came to realize that formal aspects will be learned naturally and unconsciously in the process of learning how to communicate in the target language. Language learners go through three inter language development needs to direct their focus on the formal properties of language (Doughty \& Williams, 1998).

\subsection{Input enhancement - drawing learners' attention to target words}

Properly, awareness has been defined as "a particular state of mind in which an individual has undergone a specific subjective experience of some cognitive content or external stimulus" (Tomlin \& Villa, 1994: p. 193). Schmidt (1990) says that "attention is the mechanism that controls access to awareness, and awareness can be operationally defined as ability for verbal report" p. 258. He discriminates two levels of awareness: a low level, 'noticing', and a high level, 'understanding', which involves metalinguistic awareness. The Noticing Hypothesis makes obvious that attention is necessary for noticing, and that noticing is necessary and sufficient for intake, whereas understanding leads to deeper learning. Schmidt notices some hypothesis; e.g. awareness at the level of learning is required for all learning (Schmidt, 1995, p.27). The "noticing hypothesis" asserts that what learners notice in input is what becomes intake for learning (Schmidt, 1995, p. 20). SLA is largely driven by what learners pay attention to and notice in target language input and what they understand the significance of noticed input to be (Schmidt, 2001, p. 3 - 4). The method of helping draw L2 learners' attention to the formal features such as grammar and vocabulary of the L2 input they are exposed to, SLA researchers have investigated the role of enhanced input. Drawing learners' attention to target language forms in otherwise primarily meaning-communication oriented situations is expected to help learners to notice the gap between their inter language and the target language. In addition, according to Schmidt's noticing hypothesis (1994) a set of pedagogical techniques to absorb learners' opinion to formal features in the L2 input and it has been named input enhancement (Sharwood-Smith, 1993). Input enhancement is expected to increase the chances that learners will pay attention to the targeted grammatical features. However, some aspects of language are noticed before others, or are not noticed at all. This is because they are "salient" in their context. 
Han, Park, and Combs (2008) found that L2 learners ignore a large amount of evidence and continue to perform with a system that is in contradiction with the target norms as manifest in the input. According to Han et al. $(2008$, p. 610) the reasons are multi-faceted:

"First, L2 learners lack sensitivity to grammatical features of target language input. Even when a large amount of input is available in their learning environment, they may not benefit from it. Second, certain grammatical features in the input enhancement development caused learners to be exposed non-salient, and their presence escapes from the learners' attention" (p. 610). Thus, learners reject to benefit from input because of lack of noticing ability on the learner's part and poor input characteristics such as lack of perceptual salience or noticeability. Schmidt (1990) hypothesizes that in order to stimulate input processing for form and meaning and therefore language learning, quality of input should be improved. The way of improving the quality of input can be "input enhancement" which is an operation where the saliency of linguistic features is increased, for example, color-coding, boldfacing, and underlining. According to Schmidt (1994) noticing is a prerequisite for learning.

Sharwood Smith (1990, p. 165) suggests that "input salience can be created by an outsider (e.g. a teacher or researcher) or by an insider (i.e. the learners). Learners possess their own natural learning and processing mechanisms which can generate input enhancement. The learner's mind is not singular or global, but rather modular in character; the learner has many minds, different linguistic domains and subsystems. When exposed to externally enhanced input, learners may or may not notice it, or may notice it partially, depending on whether or not they are ready for it. Thus whether the enhanced input will ultimately trigger the relevant mental representation is an empirical question". For example, reading a text for comprehension is a meaning-oriented situation. While reading the text, the learner's attention is on comprehension. While reading for comprehension, the learner may encounter unknown vocabulary and may not notice these words as unfamiliar. Thus, drawing learner's attention to these unfamiliar words may help him notice the words as unfamiliar. The present study, for example, uses eight target words; each target word appears six times in one text. So, words in the text, the target words were written in bold and underlined. (e.g.: How can we disentangle the truth behind long life?)

\subsection{Input Enhancement}

Input enhancement is a term which has been mostly used in recent literature of language pedagogy. Many linguists and scholars have defined input enhancement in some ways. Sharwood Smith (1991, 1993, as cited in Urano, 2000) broadly defined input enhancement as a try to make a specific linguistic form obvious to L2 learners by making characteristics of input. In Wikibook (2006) it is defined as a group of techniques for concentrating learners' attention on aspects of the language that may otherwise go waste. Input enhancement, first referred to as "consciousness-raising" by Sharwood Smith (1993), is an example of an implicit means of promoting students' noticing. It might take the form of input flooding, that is, increasing the number of times that student encounter the target structure in a particular text. Another possibility of enhancing the input is for the teacher to modify the text features in some fashion, such as bolding the target structures to make them more salient to students. The latter form is called typographical input enhancement which will be discussed in the following section. Input enhancement has been considered as one of the techniques in focus on form instruction.

\subsection{The Importance of Input Enhancement}

Significantly, input enhancement play an important role so, Sharwood Smith (1994) asserts, "Whether the enhancement is subtle or very explicit, the learner's brain must still register it. What we know of learners includes the fact that they are very good at ignoring what appears to the outside observer to be very obvious; this is why we need to do a great deal of research on the matter to see what works best." (p. 181)

\section{Method}

This study was a quasi-experimental and because of the limited participants, there is no randomization. A proficiency test was used to make clear that all of the students in the four groups were homogenous and that they were in the same level. The independent variable is investigating the effectiveness of input enhancement which consists of bolding, capitalizing, and underlining while the dependent variable is vocabulary learning. The students randomly were put into four groups, three experimental groups getting different inputs in the texts compared with one control group which received no treatment. The first class was given some texts by making bold the target words, the second class received the same texts by underlining the target words and the third class got the same texts by capitalizing the target words and the fourth group entitled for control group didn't receive any treatment or input enhancement instructions. Besides, the groups weren't informed which they were evaluated on vocabulary, not to direct their attention to the vocabulary. Consequently, findings were more important and understandable, so learners liked to use and apply them because of their comprehensiveness and learners' interest in some special inputs than others. Having answered the required tests and questions, the elicited data statistically were analyzed and interpreted. Finally, the results of the experimental groups were compared and contrasted with control group and the effects of the training were manifested.

\subsection{Materials}

Data collection was done by comparing the results of the participants in four groups and they were compared with each other and also with control group. Oxford University and Cambridge University (2001) placement test was administrated as a proficiency test and it was given to the participants before the instruction, to insure the homogeneity 
of all groups regarding their General English Proficiency. Besides, two texts by making the target words bold, capitalized, and underlined to the determined groups were provided and conducted to find out the different results of input enhancements. Finally, results were compared with control group and also the other groups in order to find which group did better than the other ones. The instructions were to figure out if bolding, capitalizing, and underlining the target words were statistically effective in learners' vocabulary acquisition or not.

\subsection{Procedures}

In the main study, first of all, the participants received a proficiency test to ensure that they have similar proficiency level and they are in the correct level. Then, according to the results of the tests, the students who got a score between 20 and 40 were selected as homogeneous ones. The participants were put into three experimental and one control groups, so experimental groups received two same texts by applying the input enhancement, such as bolding, capitalizing, and underlining during the eight sessions of treatment. Each week, experimental groups got their treatment and each target words of the texts in the study appeared so many times; exposures resulted in significant word knowledge, but in control group learners only were received the texts and then they were asked to read and answer the questions without any input enhancement instruction. After reading the new words, the comprehension questions were distributed to the learners. In the end, the participants completed the questions and also the items were collected; at the end of class the subjects were informed that they would be informed about the results after conducting each test.

Finally, the participants did their tasks individually and when everybody finished within the given time, the answers of the tasks were discussed as a class activity. Data were analyzed through applying (SPSS) based on Windows Version 11.0. A homogenous test, and F-test, and one way ANOVA were applied at the .05 level of significance to answer research question. Descriptive statistics (frequency, mean, and standard deviations) were used to examine the overall strategy use. In this research, the mentioned strategies (such as bolding, underling, capitalizing) were used as independent variables, whereas vocabulary learning was regarded as dependent variable. It was intended to see whether there were noticeable effects in the use of bolding, underling, and capitalizing along with determined texts for the upper intermediate level. F-test was handled at the significant level of $p<.05$. By referring to the results of F-test, the effects of bolding, underling and capitalizing on vocabulary learning were manifested.

\subsection{Instructional and testing procedures}

Descriptive statistics of the experimental groups, distribution of groups' homogeneity based on the results of the proficiency test and the independent F-test employed to compare the results of all groups by comparing the statistics. Besides, one way ANOVA was utilized to compare test results within four groups. Then, data was assembled; a scoring methodology happened before the analysis. While the subjects and the materials were determined, the procedure commenced. All participants were at the upper intermediate level and before conducting the classes a proficiency test was administrated to find the homogeneity of the learners. Moreover, it had 60 multiple-choices questions, cloze comprehension passages, vocabulary, and grammar sections. It was used and those who scored 20-40 were chosen as the subjects of the study. During treatment period, the most important steps such as bolding, underling, capitalizing, accompanied with texts and its questions were employed. When all participants completely were awarded of the mentioned steps, two texts with multiple choice questions were selected and distributed among learners and finally papers were corrected and the scores were revealed. An F-test showed the statistics and $(p=.000<\alpha=0.05)$. The treatments were hold during eight training and reviewing sessions, which were lasted exactly 45 minutes. This normal instruction lasted about 45 minutes, (20 minutes training and 25 minutes testing).

\section{Findings}

Table 1 and 2 demonstrates the normal distribution of all four groups. For finding the normal distribution of scores in the groups, the researcher used a One-Sample Kolmogorov-Smirnov Test and according to this test, level of significance should be above the 0.05 , so placement test score is 1.088 and vocabulary test score .897 and they are more than 0.05 and as a result they are meaningful and the variables have distributed well. The results are expressed as mean $\pm \mathrm{SD}(\mathrm{N}=80)$.

Table 1. Descriptive statistics of One-Sample Kolmogorov-Smirnov Test

\begin{tabular}{|c|c|c|c|c|c|c|c|c|}
\hline & \multirow[t]{2}{*}{$\mathrm{N}$} & \multicolumn{2}{|c|}{$\begin{array}{c}\text { Normal } \\
\text { Parameters }^{\mathrm{a}, \mathrm{b}}\end{array}$} & \multicolumn{3}{|c|}{$\begin{array}{c}\text { Most Extreme } \\
\text { Differences }\end{array}$} & \multirow{2}{*}{$\begin{array}{c}\text { Kolmogoro } \\
\text { v-Smirnov } \\
\text { Z }\end{array}$} & \multirow{2}{*}{$\begin{array}{l}\text { Asymp. } \\
\text { Sig. (2- } \\
\text { tailed) }\end{array}$} \\
\hline & & Mean & $\begin{array}{c}\text { Std. } \\
\text { Deviation }\end{array}$ & Absolute & Positive & Negative & & \\
\hline $\begin{array}{l}\text { Placement test } \\
\text { score }\end{array}$ & 80 & 31.48 & 5.998 & .122 & .078 & -.122 & 1.088 & .187 \\
\hline $\begin{array}{l}\text { Vocabulary test } \\
\text { score } \\
\text { a. Test distributic } \\
\text { b. Calculated fro1 }\end{array}$ & $\begin{array}{l}80 \\
\text { Norn } \\
\text { ta. }\end{array}$ & 15.34 & 2.565 & .100 & .099 & -.100 & .897 & .396 \\
\hline
\end{tabular}


Table 2. Descriptive statistics of groups' normal distribution in all four groups

\begin{tabular}{|c|c|c|c|c|c|c|c|c|c|}
\hline & & \multirow[t]{3}{*}{$\mathrm{N}$} & \multirow[t]{3}{*}{ Mean } & \multirow[t]{3}{*}{$\begin{array}{c}\text { Std. } \\
\text { Deviation }\end{array}$} & \multirow[t]{3}{*}{$\begin{array}{l}\text { Std. } \\
\text { Error }\end{array}$} & \multicolumn{2}{|c|}{$\begin{array}{l}95 \% \text { Confidence Interval } \\
\text { for Mean }\end{array}$} & \multirow[t]{3}{*}{$\begin{array}{l}\text { Mini } \\
\text { mum }\end{array}$} & \multirow[t]{3}{*}{$\begin{array}{l}\text { Maxi } \\
\text { mum }\end{array}$} \\
\hline & & & & & & Lower & Upper & & \\
\hline & & & & & & Bound & Bound & & \\
\hline \multirow{5}{*}{$\begin{array}{r}\text { Placement test } \\
\text { score }\end{array}$} & Bolding & 20 & 31.75 & 6.373 & 1.425 & 28.77 & 34.73 & 20 & 40 \\
\hline & Underlining & 20 & 30.90 & 5.748 & 1.285 & 28.21 & 33.59 & 20 & 40 \\
\hline & Capitalizing & 20 & 32.25 & 5.609 & 1.254 & 29.62 & 34.88 & 22 & 40 \\
\hline & Control & 20 & 31.00 & 6.569 & 1.469 & 27.93 & 34.07 & 20 & 40 \\
\hline & Total & 80 & 31.48 & 5.998 & .671 & 30.14 & 32.81 & 20 & 40 \\
\hline
\end{tabular}

According to the descriptive findings of the quasi-experimental, the first variable is the bolding $(31.75 \pm 6.37)$. Additionally, the second variable is underlining factor $(30.90 \pm 5.74)$. Furthermore, this table indicates capitalizing

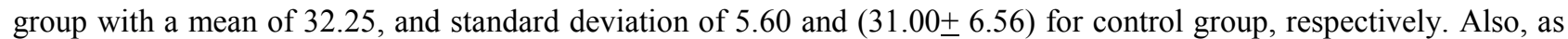
we discussed earlier, this table shows the range of scores between 20-40 for upper intermediate students in this study in a 60 item placement test, so the mean of the scores emphasize that groups are in the correct order and they have been distributed appropriately. The researcher assumed, all the learners are in the upper intermediate level and subjects are homogeneous.

Table 3. Results of homogeneity of variances in groups

\begin{tabular}{lcccc}
\hline & $\begin{array}{c}\text { Levine } \\
\text { Statistic }\end{array}$ & df1 & df2 & Sig. \\
\hline Placement test score & .632 & 3 & 76 & .597 \\
\hline
\end{tabular}

Table 4. ANOVA results of homogeneity in groups

\begin{tabular}{rrrrrrr}
\hline & & $\begin{array}{c}\text { Sum of } \\
\text { Squares }\end{array}$ & df & $\begin{array}{r}\text { Mean } \\
\text { Square }\end{array}$ & F & Sig. \\
& Between & 24.650 & 3 & 8.217 & .222 & .881 \\
Placement test & Groups & & & & \\
score & Within Groups & 2817.300 & 76 & 37.070 & & \\
& Total & 2841.950 & 79 & & \\
\hline
\end{tabular}

By comparing the results related to the placement test scores, the researcher used the analysis variance method and if sig $<0.05$, the null hypothesis is rejected. So, sig. is .881 and it is above 0.05 and the equality of variances would be approved. Also the meaningful analysis of variance is .597 and it is above 0.05 so the null hypothesis is not rejected and as a result the placement scores in the four groups didn't have a meaningful differences.

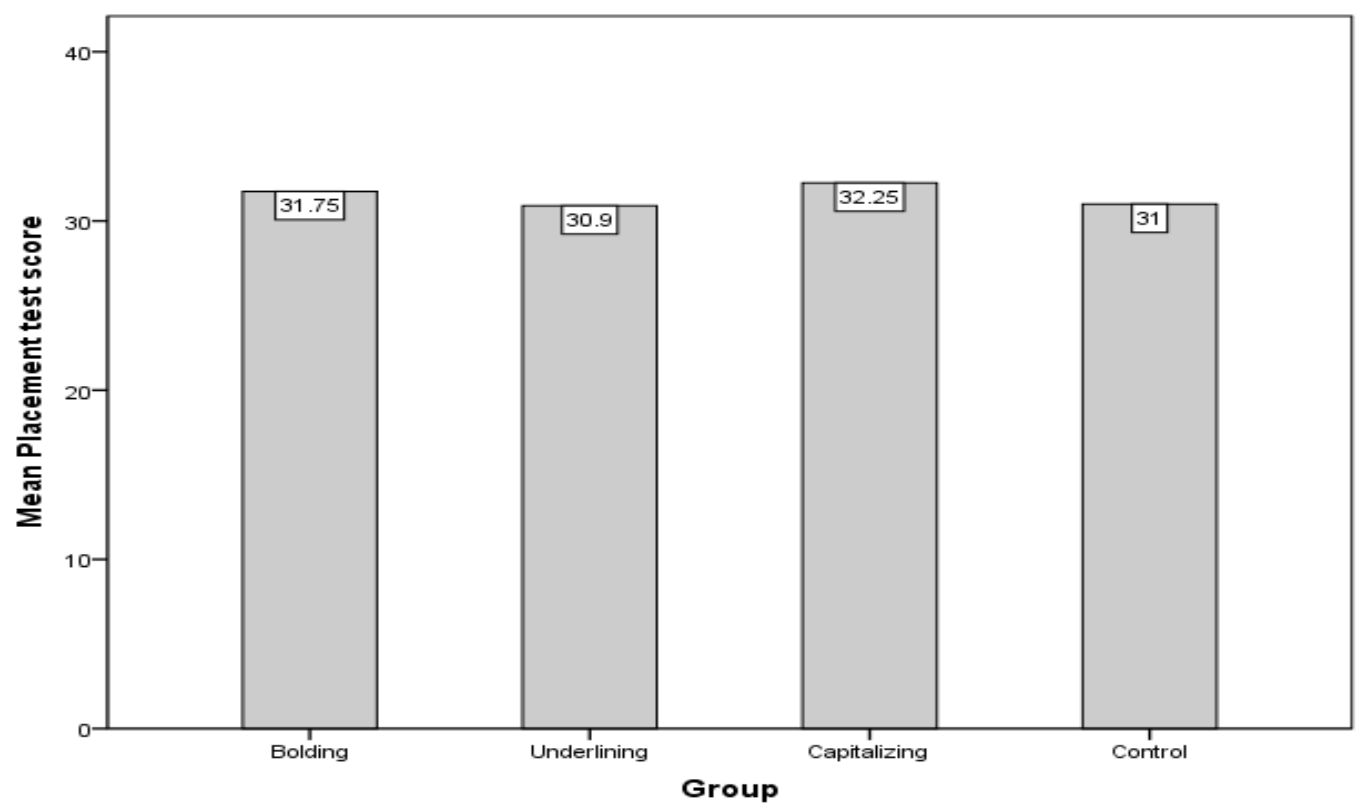

Figure 1. Histogram of learners' homogeneity in four groups 


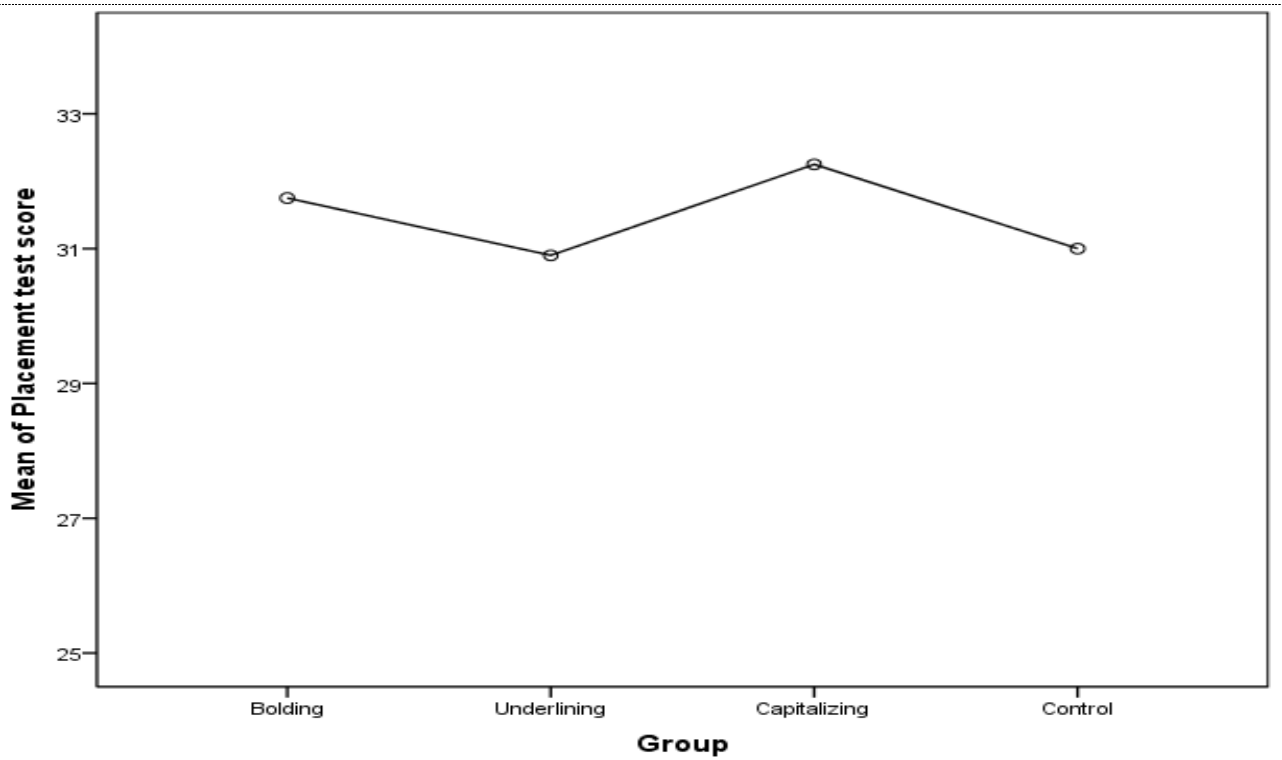

Figure 2. Means plots of homogeneity in different groups

Table 5. Descriptive statistics of vocabulary in all four groups

\begin{tabular}{|c|c|c|c|c|c|c|c|c|c|}
\hline & & \multirow[t]{2}{*}{$\mathrm{N}$} & \multirow[t]{2}{*}{ Mean } & \multirow[t]{2}{*}{$\begin{array}{c}\text { Std. } \\
\text { Deviation }\end{array}$} & \multirow[t]{2}{*}{$\begin{array}{l}\text { Std. } \\
\text { Error }\end{array}$} & \multicolumn{2}{|c|}{$\begin{array}{c}\text { 95\% Confidence } \\
\text { Interval for } \\
\text { Mean }\end{array}$} & \multirow[t]{2}{*}{ Minimum } & \multirow[t]{2}{*}{ Maximum } \\
\hline & & & & & & $\begin{array}{l}\text { Lower } \\
\text { Bound }\end{array}$ & $\begin{array}{l}\text { Upper } \\
\text { Bound }\end{array}$ & & \\
\hline \multirow{5}{*}{$\begin{array}{r}\text { Vocabulary } \\
\text { test score }\end{array}$} & Bolding & 20 & 17.95 & 1.605 & .359 & 17.20 & 18.70 & 15 & 20 \\
\hline & Underlining & 20 & 15.75 & 2.023 & .452 & 14.80 & 16.70 & 12 & 20 \\
\hline & Capitalizing & 20 & 14.30 & 2.342 & .524 & 13.20 & 15.40 & 10 & 19 \\
\hline & Control & 20 & 13.35 & 1.599 & .357 & 12.60 & 14.10 & 10 & 16 \\
\hline & Total & 80 & 15.34 & 2.565 & .287 & 14.77 & 15.91 & 10 & 20 \\
\hline
\end{tabular}

The results of the descriptive statistics for vocabulary in all four groups during the eight sessions of the study are presented in the Table 5. Table 5 categorizes mean and standard deviation of bolding, underlining, capitalizing and control groups' vocabulary tests. Learners, who received different inputs, had varied mean and standard deviations. Consequently, as it is clear, the bolding group's mean is achieved by 17.95 and standard deviation by 1.60 , underlining group's mean is 15.75 with standard deviation of 2.02, and mean of 14.30 and standard deviation of 2.34 are respectively devoted to capitalizing group and finally, (13.35 \pm 1.59$)$ was devoted to the control group. At last, bolding group did better than other groups and it shows its significance and valued effects on participants when answering the vocabulary questions.

Table 6. ANOVA results of vocabulary in all groups

\begin{tabular}{rrrcccc}
\hline & & $\begin{array}{c}\text { Sum of } \\
\text { Squares }\end{array}$ & df & $\begin{array}{c}\text { Mean } \\
\text { Square }\end{array}$ & F & Sig. \\
& Between & 240.437 & 3 & 80.146 & 21.797 & .000 \\
Vocabulary test & Groups & & & & & \\
score & Within Groups & 279.450 & 76 & 3.677 & & \\
& Total & 519.887 & 79 & & & \\
\hline
\end{tabular}

Table 7. Results in Test of Homogeneity of Variances among all groups

\begin{tabular}{|c|c|c|c|c|}
\hline & $\begin{array}{c}\text { Levine } \\
\text { Statistic }\end{array}$ & df1 & $\mathrm{df} 2$ & Sig. \\
\hline $\begin{array}{r}\text { Vocabulary test } \\
\text { score }\end{array}$ & 1.254 & 3 & 76 & .296 \\
\hline
\end{tabular}

In the present study, the significant level is $p<0.05$. According to table 6 and 7 and based on the ANOVA series tests and Levin test which is used in this stage, it is observed that $\operatorname{sig}=.000$ and $F=21.797$, so it could be inferred that noticeable differences exist among the results of input enhancement effects on vocabulary test scores in different groups 
of learners. Additionally, as it is clear in above tables and as discussed earlier, the results indicate that the computed $\mathrm{F}$ observed value, is 21.797 , and also the level of significance $(0.000)$ is less than 0.05 . Therefore, the differences between groups are statistically significant and it means that the groups with different strategy use, performed differently after receiving distinct types of treatments. Furthermore, the null hypotheses which state that bolding, capitalizing, and underlining target words do not have any significant effect on L2 vocabulary learning was rejected and the directional hypothesis was confirmed. In statistics when the researcher reaches these results, it means that the researcher should reject the null hypothesis of the study and consequently confirm the directional ones. In conclusion, since the researcher reached significant differences between four groups, a post-hoc comparison test was used in order to compute the isolations where the significant differences exactly lay among the groups (with an alpha level of .05).

Table 8. Multiple comparisons of vocabulary tests results in bolding, underlining, capitalizing and control groups

\begin{tabular}{|c|c|c|c|c|c|c|c|}
\hline \multicolumn{8}{|c|}{ Multiple Comparisons } \\
\hline \multirow[t]{4}{*}{ Dependent Variable } & \multirow[t]{4}{*}{ (I) Group } & \multirow[t]{4}{*}{ (J) Group } & \multirow{4}{*}{$\begin{array}{c}\text { Mean } \\
\text { Difference } \\
(\mathrm{I}-\mathrm{J})\end{array}$} & \multirow{4}{*}{$\begin{array}{l}\text { Std. } \\
\text { Error }\end{array}$} & \multirow[t]{4}{*}{ Sig. } & \multirow{2}{*}{\multicolumn{2}{|c|}{$\begin{array}{l}95 \% \text { Confidence } \\
\text { Interval }\end{array}$}} \\
\hline & & & & & & & \\
\hline & & & & & & Lower & Upper \\
\hline & & & & & & Bound & Bound \\
\hline \multirow{12}{*}{$\begin{array}{c}\text { Vocabulary } \\
\text { test score }\end{array}$} & Bolding & Underlining & $2.200^{*}$ & .606 & .001 & .99 & 3.41 \\
\hline & & Capitalizing & $3.650^{*}$ & .606 & .000 & 2.44 & 4.86 \\
\hline & & Control & $4.600^{*}$ & .606 & .000 & 3.39 & 5.81 \\
\hline & Underlining & Bolding & $-2.200^{*}$ & .606 & .001 & -3.41 & -.99 \\
\hline & & Capitalizing & $1.450^{*}$ & .606 & .019 & .24 & 2.66 \\
\hline & & Control & $2.400^{*}$ & .606 & .000 & 1.19 & 3.61 \\
\hline & Capitalizing & Bolding & $-3.650^{*}$ & .606 & .000 & -4.86 & -2.44 \\
\hline & & Underlining & $-1.450^{*}$ & .606 & .019 & -2.66 & -.24 \\
\hline & & Control & .950 & .606 & .121 & -.26 & 2.16 \\
\hline & Control & Bolding & $-4.600^{*}$ & .606 & .000 & -5.81 & -3.39 \\
\hline & & Underlining & $-2.400^{*}$ & .606 & .000 & -3.61 & -1.19 \\
\hline & & Capitalizing & -.950 & .606 & .121 & -2.16 & .26 \\
\hline
\end{tabular}

The mean difference is significant at the .05 level.

Dependent Variable: vocabulary learning

The results of post hoc comparisons are manifested in Table 8. They revealed significant differences among the groups. Additionally, in order to compare paired comparison in the study, post-hoc test was used. The results were manifested by comparing the other groups, so the bolding group acquired statistically significant higher than other ones and capitalizing accompanied with control group acquired statistically low. To summarize, these results led the researcher to conclude that although providing input enhancements strategies have positive effects on learners' performance in general, the bolding input is more effective than the other chosen inputs. Furthermore, a brief look makes it clear that the bolding group outperformed both the capitalizing and the underlining groups in spite of their valuable effects on learning the target words, and this difference was statistically significant $(p=.000)$ at the 0.05 level of significance $(p<\alpha)$. This led the researcher to certify the alternative hypotheses and to accept the differences and confirm that bolding as the most significant factor compared to capitalizing and underlining input enhancements.

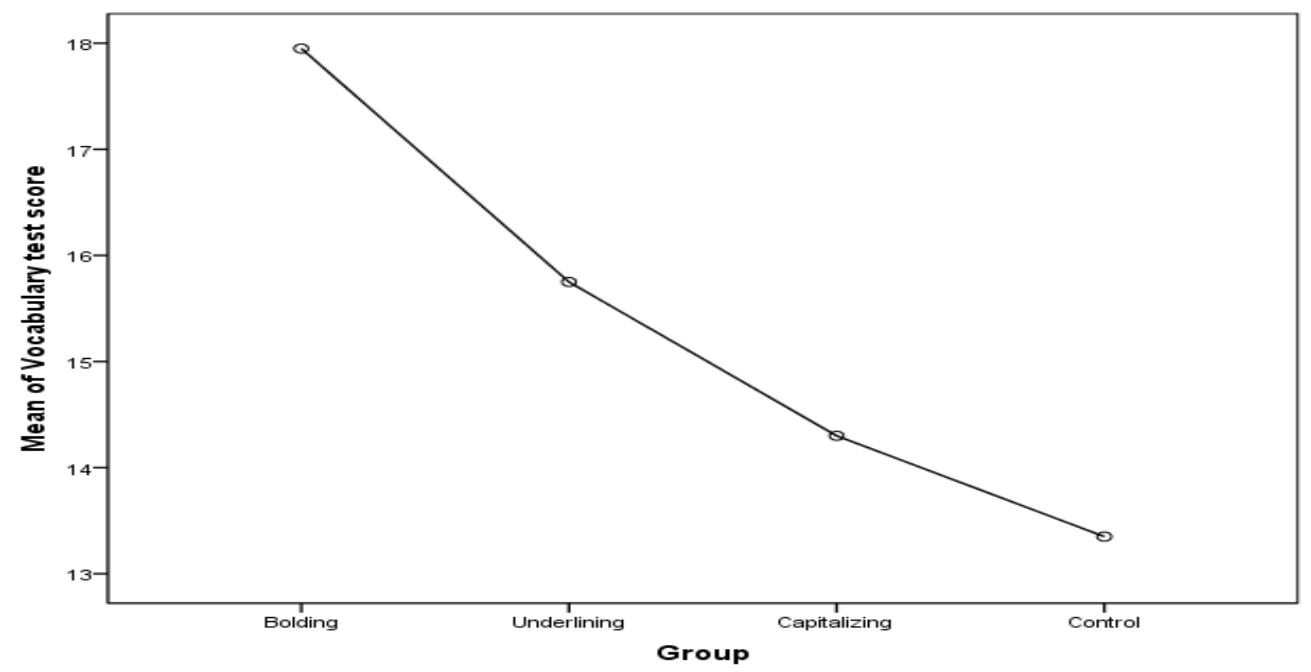

Figure 3. Means plots of bolding, underlining, capitalizing and control groups 
These descriptive statistics results obtained from the quasi-experimental research described the most and least frequently used strategies respectively as bolding and capitalizing inputs with control group.

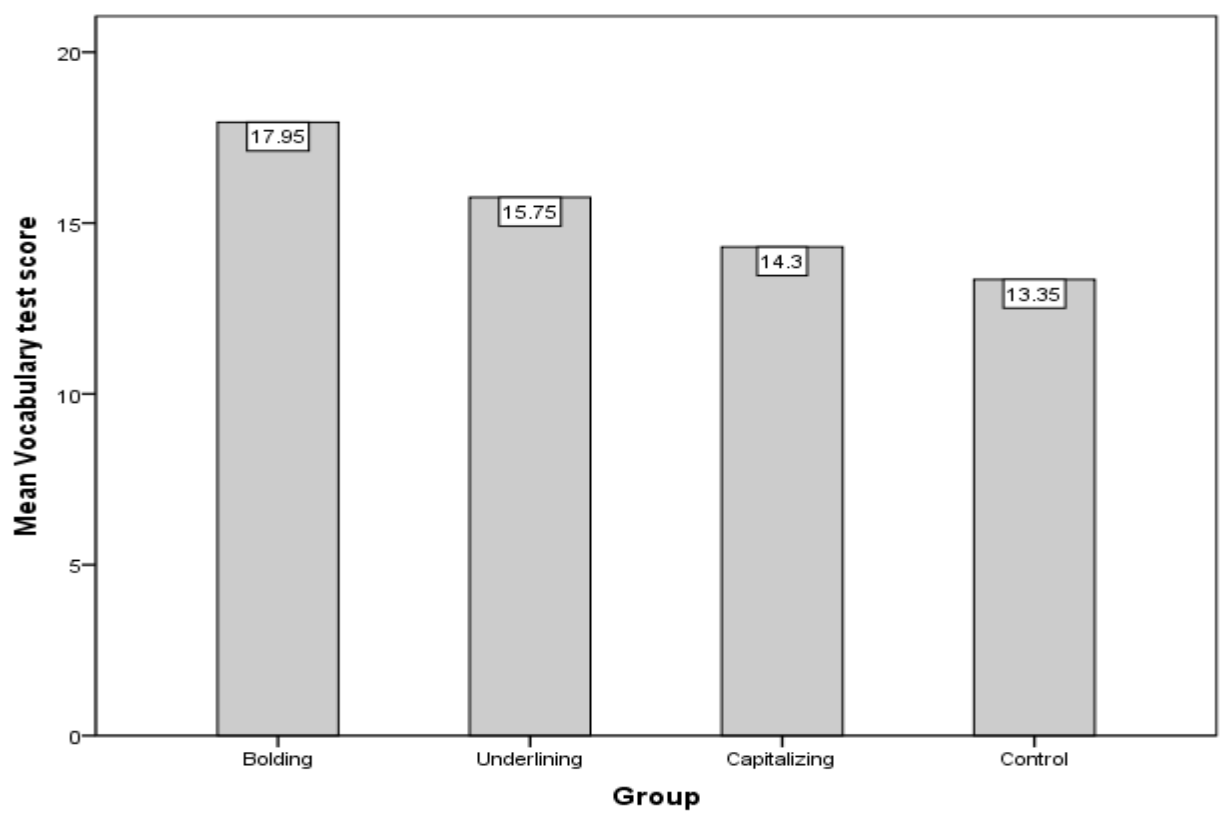

Figure 4. Histogram of learners' vocabulary test results in four groups

\section{Discussion}

To be honest, this section provides a significant clarification for the research question and tries to join every result to the present manifestation. Results emphasized that bolding group did better than the underlined, capitalized and control groups. The participants were 80 upper intermediate English learners in International Language Institute in Tabriz. The materials were two texts including some vocabulary questions. Some target words were used for testing, so study declared that there is positive impact of input enhancement on L2 target features learning. In conclusion, the findings of our research are in line and related with the findings of Shook's (1994) research and clarified that input enhancement items were effective in developing learners' vocabulary knowledge and this input has a positive impact on students' vocabulary progression. The results were satisfactory and it can be concluded that input enhancement is a necessary and effective technique to learners.

In order to ascertain how much homogeneity there is among them, 80 learners out of 100 were chosen to act as participants of this study. Questions were given from Oxford University press and Cambridge University local examination syndicate. Learners were randomly divided into four groups, each of which was treated using one of the four main input enhancement branches; that is to say, bolding, underlining, capitalizing and control groups. The SPSS software was used to analyze the obtained data, which was consisted of descriptive statistics and analytical method (one way ANOVA, and LSD or post-hoc test). Also, the findings of the descriptive statistics were shown on tables and plots. Therefore, the present chapter covers the findings of the conducted research to its research question and hypotheses. In this study, the findings showed the frequency of employing input enhancement items and also performing them in the classes which may help learners to enhance their ability to answer, also it was learnt that the group with the highest mean performed better. Then, the distinctions and contrasts among the groups which had the vocabulary tests' mean lower than the other ones were open to survey. In the end, these findings might help us to understand that when vocabulary texts are accompanied with some particular inputs; at that time the results of the tests would be better and more useful than the other circumstances. Additionally, the reason behind the positive impact of input enhancement is the learners' cognitive processing system and the factor "noticing". Sharwood Smith (1993) described the logical for input enhancement, that is, we can develop the learners' selection process of input by enhancing the perceptual saliency of certain targeted forms in the input. This process would appear to engage the learners' attention as a selective process as it includes directing the learners' focal attention to a certain form an array of verbal or written forms (Combs, 2006).

\section{Conclusion}

As previously highlighted, the main focus of the study was to understand which input enhancement item; bolding, capitalizing, underlining affects learners' vocabulary knowledge more. In order to obtain some concrete evidence, the written data were applied to a series of ANOVAs and post hoc test or LSD comparisons. The results of these tests were an indication of the statistically significant differences among the experimental and control groups. By applying different input enhancements and especially bolding, learners can do their best to find new ways of learning; they are more interested learners and can solve their problems and difficulties in vocabulary learning and use their vocabulary knowledge to better grasp the main points and ideas in texts and passages. So, the researcher here tried to find the different categories of input enhancement as an effective way of enhancing learners' vocabulary knowledge, especially bolding, in particular, was the most efficient one among the other ones. According to the results of the study, awareness raising administered through contrastive analysis helps the poor readers to enhance their perceptual understanding of the 
target complicated features by using various techniques such as bolding, capitalizing, underlining and highlighted form of reading comprehension texts in contrast to control group.

In conclusion, it appears that instruction of awareness-raising through comparing and analyzing can affect comprehension of students at the upper intermediate level of English vocabulary proficiency. Moreover, this study supports Ellis' recommendations (Ellis, 2002), concerning usage of explicit knowledge and implies that we must use explicit knowledge rather than implicit knowledge in teaching complicated structures of the target language (Ellis, 1997, p. 164). Therefore, observance of the sequence ranging from easy to difficult, simple to complex and familiar to unfamiliar when teaching foreign language structures to EFL learners, must be taken into consideration. The most important belief for such a result originates from the works of Sharwood Smith (1991, 1993, 1994), who is the founder of input enhancement. Furthermore, it can be noticed that the findings of this study maintains to Sharwood Smith's beliefs (1994) that input enhancement has a positive impact on the rate and accuracy of L2 acquisition.

Besides, the results of the research question provide further empirical support for (Doughty, 1988; Shook, 1994; Williams, 1999). Also the null hypotheses, stating that Bolding, underlining, and capitalizing the target words do not have any significant impact on L2 vocabulary learning as opposed to non-bolding, non-underlined, and non-capitalized target words, were also rejected. According to the findings of the present study, all the methods of visual/textual input enhancement were beneficial to learning. Furthermore, the results obtain from this research is testimony to the facilitative role of formal instruction in second language acquisition. Besides, the present results are considered to run counter to Krashen's (1982) manifestations that comprehensive input is vital and sufficient requirement for L2 acquisition, and that there is no need for formal instruction.

As a result, it can be suggested based on the comparison made between groups one, two, three and 4 that language learners have a limited capacity in noticing and they cannot attend to all aspects of L2 input. As previously discussed, the participants in group one received the same vocabulary text materials as those in group two, three and four did. However, for the students in group one, the specific category of lexical collocations in focus made salient via bolding and underlining for the second group and CAPITALIZING for the third and no treatment for the last group. It has to be noted that, these subjects were indirectly helped to notice target items which made up for their limited capacity in noticing. Therefore, they indicated a good gain of input as well as vocabulary knowledge.

\subsection{Pedagogical implications}

Absolutely, there is also another basic pedagogical implication which emerges from this study: focus on form treatments involving implicit technique as input enhancement can be conducted within task based teaching stated in previous chapters and "input enhancement" is a technique used to draw learners' attention to certain linguistic features. The results of this also confirm the claim that guiding learners to focus on form within meaning-oriented instruction based on cognitive theories of L2 acquisition is definitely fruitful. The findings of this study are expected to have useful implications for language learners and teachers in their long process of learning vocabulary. This study will be conducted in order to fill a void in input enhancement research into vocabulary instruction. It is expected that instructing new vocabulary accompanied by bolding target words will lead to statistically more effective learning of vocabulary.

This research might be helpful for both teachers and students because by using these input enhancement devices not only students can overcome vocabulary comprehension problems but also teachers with a high self-confidence can have a general view and work out solutions to better understanding of new and target vocabulary in texts through bolding, underlining, and capitalizing method in order to be the best teachers and learners.

\subsection{Limitations of the study}

This study is limited in that there aren't as many subjects as ideally needed for this apparently comprehensive study. Participants are all homogenous from male groups and there are no female participants involved in this study. The learners might not be able to show their capability and efficiency in this study. Obviously, no research study would be complete and without any limitations, and this study seems to have its' own shortcomings that need to be addressed. The results were based on four classes of upper intermediate students in English Institute. If the groups were examined again, different outputs might come to surface, not to mention almost all classroom studies have their own drawback such as the length of own drawbacks, treatment sessions and the classes being single sexed.

\subsection{Suggestions for Further Research}

Inferences can be drawn from results of this study are limited by the nature of the particular sample selected, which solely consisted of upper intermediate students of International Language Institute. Further research can also explore the use of inputs of other categories such as italicized and other ones that by employing them, we can be familiar with the details of input enhancements. Also, it would be interesting to know which students are the most predisposed to employ these inputs during a new vocabulary tests. And it can be recommended that in further research, other researchers investigate these inputs at university classes. Also because of some problems, the researcher was not able to include intervening variables such as age in his research; however, it is suggested that such intervening variables are included in the further studies. 


\section{References}

Alanen, R. (1995). Input enhancement and rule presentation in second language acquisition. In R. Schmidt (Ed.), Attention and awareness in foreign language learning. Honolulu: University of Hawai'i Press.

Coady, J. (1993). Research in ESL/EFL vocabulary acquisition; putting it in context. In T. Huckin, M. Hynes and J.Coady (Eds). Second Language Reading and Vocabulary Learning, 3-23. Norwood.

Coady, J. (1997). L2 vocabulary acquisition through extensive reading. In J. Coady \& T. Huckin (Eds.). Second Language Vocabulary Acquisition, 225-237. New York, NY: Cambridge University Press.

Coady, J., \& Huckin, T. (1997). Second Language Vocabulary Acquisition. New York, NY: Cambridge University Press.

Coady, J.,\& Huckin, T. (1999). Incidental vocabulary acquisition in a second language: A review. Studies in second language acquisition, 21 (2), 181-192.

DeKeyser, R.M. (2000). The robustness of critical period effects in second language acquisition. Studies in Second Language Acquisition, 22, 499-533.

Dekeyser (1998) Form-meaning connections in second language acquisitions

Doughty, C. (1991). Second language acquisition does make a difference: evidence from an empirical study of SL relativization. Studies in Second Language Acquisition, 13(3), 431-469.

Doughty, C.J. (2003). Instructed Second Language Acquisition: Constraints, compensation and enhancement. In C.J. Doughty and M.H. Long (Eds.). The Handbook of Second Language Acquisition, 256-310. Malden, MA: Blackwell.126

Doughty, C.J.,\& Varela, E. (1998). Communicative focus on form. In C.Doughty \& J. Williams (Eds.). Focus on Form in Classroom Second Language Acquisition, 114-138. New York: Cambridge University Press.

Doughty, C., \& Williams, J. (1998). Focus on form in classroom second language acquisition. Cambridge: CUP.

Ellis, Nick C. (1997). Introduction: implicit and explicit language learning-an overview. In Ellis, Nick (ed.). Implicit and explicit learning of languages, 1-31. London: Academic Press.

Ellis, R. (2001). Form-focused instruction and second language learning. Language Learning, 51 (Suppl.1).

Ellis, R., Baştürkmen, H., \& Loewen, S. (2001). Preemptive focus on form in the ESL classroom. TESOL Quarterly, 35(3), 407-432.

Ellis, N.C., Beaton, A. (1993). Psycholinguistic determinants of foreign language vocabulary learning. Language Learning, 43(4), 559-617.

Ellis, T.R. (2002c). Recent developments in International valuation standards, " in SME transactions 2002, Vol. 312 , pp. 148-152.

Han, Z., Park, E.S., \& Combs, C. (2008). Textual enhancement of input: Issues and possibilities. Applied Linguistics, 29(4), 597-618.

Kim,Y. (2006). Effects of input elaboration on vocabulary acquisition through reading by Korean learners of English as a foreign language. TESOL Quarterly, 40(2), 341-373.

Kim, Y. (2008). The Role of Task-Induced Involvement and Learner Proficiency in L2 Vocabulary Acquisition. Language Learning, 58(2), 285-325.

Krashen, S.D. (1982). We acquire vocabulary and spelling by reading: Additional evidence for the input hypothesis. Modern Language Journal, 73, 440-464.

Krashen, S.D. (1997). The comprehension hypothesis: Recent evidence. English Teachers' Journal (Israel), 51, $17-29$.

Lee, S.H. (2007). Effects of textual enhancement and topic familiarity on Korean EFL students reading comprehension and learning of passive form. Language Learning, 57(1), 87-118.

Lee, S.H. (2003). ESL learners' vocabulary use in writing and the effects of explicit vocabulary instruction. System, 31, 537-561.

Leeman, J., Arteagoitia, I., Fridman, B., \& Doughty, C. (1995). Integrating attention to form with meaning: Focus on form in content-based Spanish instruction. In R. Schmidth (ed.): Attention and Awareness in Foreign Language Learning, 217-258. Retrieved March 12, 2009, from http://books.google.com/books/.131

Leow, R. (1993). To simplify or not to simplify: A look at intake. Studies in Second Language Acquisition, 15, 333-55.

Leow, R.P. (1997). The effects of input enhancement and text length on adult L2 readers comprehension and intake in second language acquisition. Applied Language Learning, 8, 151-182.

Leow, R.P. (2001). Attention, awareness and foreign language behavior. Language Learning, 51, 113-155.

Long, M.H. (1997). Focus on form in task-based language teaching. Retrieved February 9, 2009 from http:// www.mhhe.com/socscience/foreignlang/top.htm

Long, M.H. (1996). The role of linguistic environment in second language acquisition. In W.C.B. Ritche, K.Tej (Eds.). Handbook of Second Language Acquisition, 413-468. SanDiego: Academic Press,Inc. 
Long, M. H. \& Robinson, P. (1998). Focus on form: theory, research and practice. in focus on form inclassroom L2 Acquisition, C. Doughty \& J.Williams (Eds.), pp. 85-114. New York: Cambridge.

Overstreet, C. 1998. Nematodes in the Mid-South. 1998 Beltwide Cotton Conferences Proceedings Volume 1:172-173.

Poole, A. (2005). Focus on form instruction: Foundations, applications, and criticisms. The Reading Matrix: An International Online Journal, 5(1).

Robinson, P. (1996). Learning simple and complex language rules under implicit, incidental, rule search, and instructed conditions. Studies in Second Language Acquisition, 18, $27-76$.

Schmidt, R. (1990). The role of consciousness in second language learning. Applied Linguistics, 11(2), 129-158.

Schmidt, R. (1993). Implicit learning and the cognitive unconscious: Of artificial grammars and SLA. In N. Ellis (Ed.). Implicit and explicit learning of languages, 165-209. London: Academic Press.

Schmidt, R. (1995). Consciousness and foreign language learning: A tutorial on the role of attention and awareness in learning. In R.W. Schmidt (ed.), Attention and awareness in foreign language learning and teaching. Honolulu, Ha: University of Honolulu, 1-63.

Schmidt, R. (2001). Attention. In P. Robinson(ed.). Cognition and second language instruction. Cambridge:CUP.136.

Schmitt, N. (2000). Vocabulary in Language Teaching, Cambridge: CUP.

Schmitt, N. (2008). Review article: Instructed second language vocabulary learning. Language Teaching Research, 12(3), 329-363.

Schmitt, N., \& Schmitt, D. (1995). Vocabulary notebooks: Theoretical underpinnings and practical suggestions. ELT Journal, 49(2), 133-143.

Seedhouse, P. (1997). Combining form and meaning. English Language Teaching Journal, 51(4), 336-344.

Sharwood-Smith, M. (1991) Teaching Grammar in Second Language Classrooms: Integrating Form-Focused Instruction in Communicative Context.

Sharwood-Smith, M. (1993). Input enhancement in instructed second language acquisition: Theoretical bases. Studies in Second language acquisition, 15, 165-179.

Sheen, Y. (2002) Yellow umbrella. Kane/Miller Book Pub.

Sheen, R. (2000). Review: Doughty \& Williams: Focus on Form in SLA. Ronald Sheen $<$ Ronald_Sheen @ UQTR. UQebec.CA>.

Shook, D. (1994). FL/L2 reading, grammatical information, and input-to-intake phenomenon. Applied Language Learning, 5, 57- 93.

Tomlin, R. S., \& Villa, V. (1994). Attention in cognitive science and second language acquisition. Studies in Second Language Acquisition, 16, 183-203.

Urano, K. (2000). Lexical simplification and elaboration: sentence comprehension and incidental vocabulary acquisition (Unpublished Master's thesis). University of Hawai'i at Manoa, Honolulu.

White, J. (1998). Getting the learners' attention: A typographical input enhancement study. In C. Doughty, and J. Williams (Eds.), Focus on Form in Second Language Acquisition, 85-113. Cambridge: CUP.138

Williams, J. (1999). Memory, attention, and inductive learning. Studies in Second Language Acquisition, 21, 1-48. 